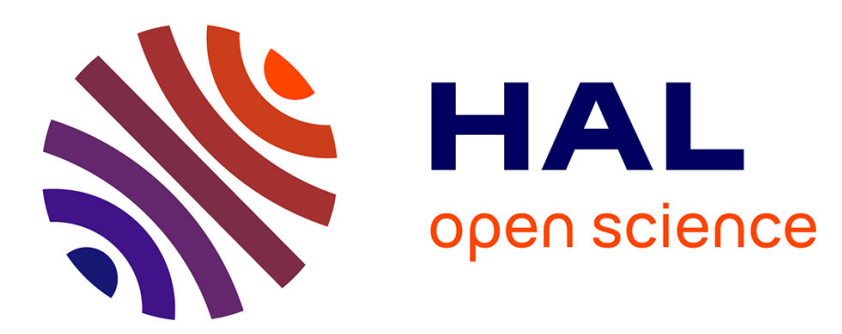

\title{
FDG-PET/CT in large-vessel vasculitis: its diagnostic and follow-up role
}

Emöke Šteňová, Samuel Mištec, Pavol Povinec

\section{To cite this version:}

Emöke Šteňová, Samuel Mištec, Pavol Povinec. FDG-PET/CT in large-vessel vasculitis: its diagnostic and follow-up role. Rheumatology International, 2009, 30 (8), pp.1111-1114. 10.1007/s00296-0091038-9 . hal-00568302

\section{HAL Id: hal-00568302 \\ https://hal.science/hal-00568302}

Submitted on 23 Feb 2011

HAL is a multi-disciplinary open access archive for the deposit and dissemination of scientific research documents, whether they are published or not. The documents may come from teaching and research institutions in France or abroad, or from public or private research centers.
L'archive ouverte pluridisciplinaire HAL, est destinée au dépôt et à la diffusion de documents scientifiques de niveau recherche, publiés ou non, émanant des établissements d'enseignement et de recherche français ou étrangers, des laboratoires publics ou privés. 


\title{
FDG-PET/CT in large-vessel vasculitis: its diagnostic and follow up role
}

Emőke Šteňová ${ }^{1}$, Samuel Mištec ${ }^{1}$, Pavol Povinec ${ }^{2}$

1 1st Department of Internal Medicine, Comenius University in Bratislava, Slovakia

2 PET Centre, BIONT a.s., Bratislava, Slovakia

Corresponding author:

MUDr. Emőke Šteňová, PhD.

1st Department of Internal Medicine, Comenius University

Mickiewiczova 13

81369 Bratislava

Slovakia

Tel:+421905682321

Fax:+421257290673

e-mail: stenova@faneba.sk

\begin{abstract}
:
Vasculitis is a disorder characterized by inflammation of blood vessels. Its clinical manifestations are diverse and depend on the size of the involved vessels and the organs affected by ischemia. In some cases the disease is manifested only with symptoms and signs of systemic inflammation (e.g., fever, night sweats, fatigue,). Results of laboratory tests usually indicate only the inflammatory process. It is known that radiolabeled glucose analogue 18F- fluoro-deoxyglucose ([18F] FDG) used in positron emission tomography (PET) accumulates in both malignant and inflammatory tissue (1). We report a case of a patient with FDG-PET/CT findings of large vessel vasculitis with follow-up results that convinced us to change the treatment.
\end{abstract}

Key words: vasculitis, PET, fluoro-deoxyglucose, diagnosis, follow-up 


\section{Case}

69-year-old Caucasian woman was admitted to local hospital because of fatigue, sweating, anorexia, recurrent fever at $38-39 \stackrel{\circ}{\circ}, 4 \mathrm{~kg}$ weight loss in one month. There were no symptoms of specific organ damage and the physical examination was without abnormalities. Laboratory studies showed elevated ESR 100/ hour, C-reactive protein 192mg/l and hypochromic anaemia with haemoglobin $97 \mathrm{~g} / \mathrm{l}$. Hepatic transaminase activity was slightly elevated, kidney function tests were normal. Infectious aetiology was not the probable cause of inflammation (no bacterial growth in urine and haemocultures, negative serological tests and PPD skin test). Thoracic radiography was without inflammatory changes. Abdominal and pelvic ultrasound imaging were unremarkable. Autoantibodies ANA, ASMA, AMA were negative. The thoracoabdominal CT scan was performed and has shown the thickening of aorta wall $3-4 \mathrm{~mm}$, both of superior mesenteric artery and left renal artery without stenosis.

The patient was admitted with these findings to our department. Because of suspection of autoimmune vasculitis PET/CT scan was performed. The images were remarkable for extensive abnormal [18F]FDG accumulation along the walls of the thoracic and abdominal aorta, subclavian and axillary arteries, common carotid arteries, superior mesenteric arteries, iliac arteries and upper parts of femoral arteries (Fig.1).

We initiated treatment with a high dose methylprednisolone pulse therapy with a dose $500 \mathrm{mg} /$ day and continued with $60 \mathrm{mg} /$ day of oral prednisone with good clinical and laboratory effect (no fever, decreasing of CRP). Because of large vessel changes treatment with cyclofosfamid $50 \mathrm{mg} /$ day was started as well.

Six months after the introduction of therapy (therapy at this time prednisone $20 \mathrm{mg}$, cyclophosphamid $50 \mathrm{mg} / \mathrm{day}$ ) the only symptom of the patient was night sweats, the blood count was normalized, but CRP (45.90 mg/l) and ESR (38/70) were elevated. Follow-up PET/CT scan was performed. Abnormal [18F]FDG uptake was demonstrated in thoracic aorta, subclavian and axillary arteries but of a much lower intensity as on the baseline scan (Fig.2). Combination of cyclophosphamid with cyclosporine A $100 \mathrm{mg} /$ day was administered, glucocorticoid treatment was continued. This therapy led to normalization of ESR and CRP with sustained remission after 2 months.

\section{Discussion}

This case illustrates an atypical clinical presentation of large- vessel vasculitis with no clinical symptoms of organ damage and without the possibility of verification of suspected diagnosis with biopsy. The only patient's symptoms were signs of 
systemic inflammation which are common in fever of unknown origin (FUO). The large-vessel vasculitis is considered to be the cause in $17 \%$ of all FUO patients (2).

FDG-PET is a non-invasive diagnostic method which shows the bio-distribution of positron emitter labelled radiopharmaceuticals in the body. Fluoro-deoxyglucose is accumulated in tumour cells but also in inflammatory tissue due to the over-expression of glucose -transporter (GLUT, mainly GLUT 1,3) and overproduction of glycolytic enzymes (3). FDGPET is highly effective in detecting large vessel vasculitis anywhere in the body and has high sensitivity (77-100\%) and specificity (89-100) (3). The percentage of PET scans helpful in the diagnostic process in patients with FUO varied from 41 to $69 \%$ (4). Combination of CT and PET images has an advantage of direct correlation of pathological changes in metabolic activity with precise anatomical localization in one fusion image. The residual FDG uptake on follow-up PET/CT examination in our case correlated with laboratory and clinical activity of the disease and indicated a more intensive anti-inflammatory treatment was needed.

\section{Conclusion}

[18F]FDG-PET/CT is an effective combination of imaging modalities in assessing the activity and extent of large vessel vasculitis with high sensitivity and specificity. This investigation has also been used to follow up patients over time and to monitor response to anti-inflammatory and immunosuppressive treatment.

\section{References:}

1. Zhuang H, Yu JQ, Alavi A (2005) Applications of fluorodeoxyglucose- PET imaging in the detection of infection and inflammation and other benign disorders. Radiol Clin North Am 43:121-134 Medline. doi:10.1016/j.rcl.2004.07.005

2. Vanderschueren S, Knockaert D, Adriaenssens T, Demey W, Durnez A, Blockmans D, Bobbaers H (2003) From prolonged febrile illness to fever of unknown origin: the challenge continues. Arch Intern Med 163(9):1033-1041 Medline. doi:10.1001/archinte.163.9.1033

3. Otsuka H, Morita N, Yamashita K, Nishitani H (2007) FDG-PET/CT for diagnosis and follow-up of vasculitis J Med Inv 54:345-349.

4. Bleeker-Rovers CP, de Kleijn EM, Corstens FH, et al (2004) Clinical value of FDG PET in patients with fever of unknown origin and patients suspected of focal infection or inflammation. Eur J Nucl Med Mol Imaging 31:29-37 Medline. doi:10.1007/s00259-003$\underline{1338-3}$ 
5. Chavaillaz O, Gueddi S, Taylor S, Stalder H, Righini M (2006) Giant cell arteritis mimicking fever of unknown origin: potential diagnostic role of PET scan. Thromb Haemost 95:390-392 Medline. 
Figure captions:

Fig. 1 Baseline PET/CT scan demonstrating abnormal [18F]FDG accumulation along the walls of the thoracic and abdominal aorta, subclavian, axillary arteries, common carotid arteries, superior mesenteric arteries, iliac arteries and upper parts of femoral arteries suggestive of very active and extensive inflammation process.

Fig. 2 Follow-up PET/CT scan with abnormal [18F]FDG uptake in the thoracic aorta, subclavian and axillary arteries, but of a lower intensity in comparison to the baseline scan, consistent with persistent low-activity inflammation. 

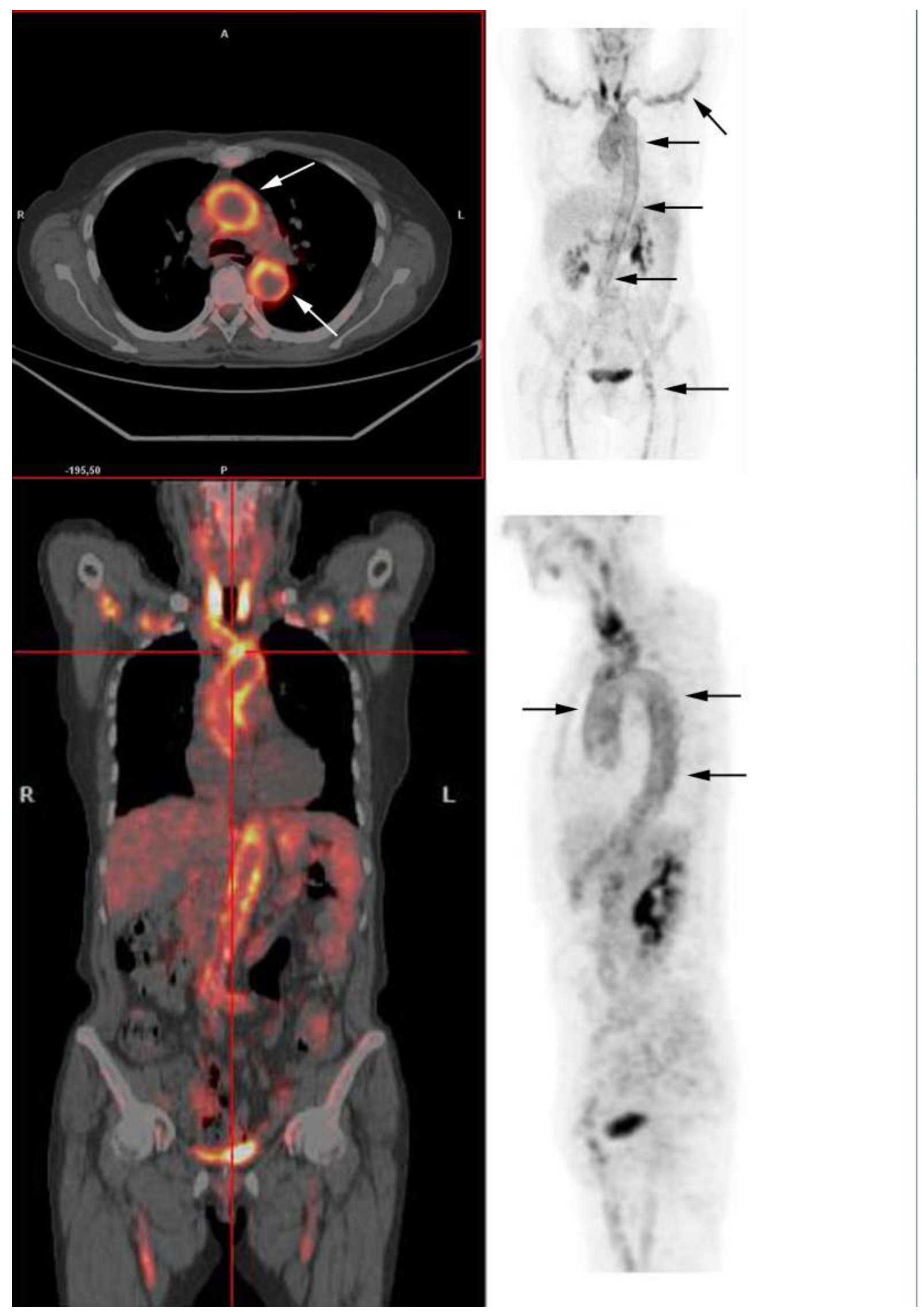


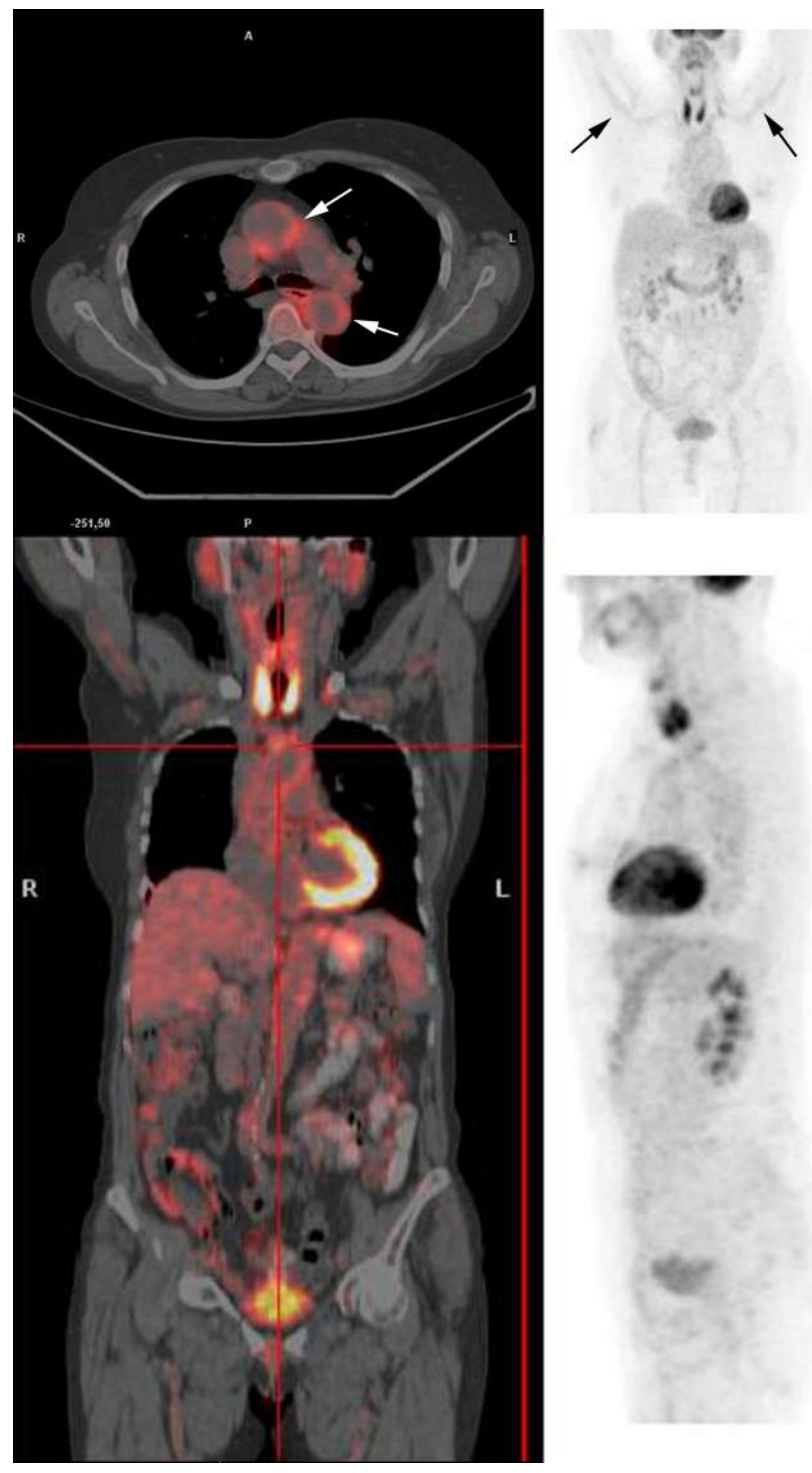

